\title{
KAJ IAN INDEKS ERODIBILITAS TANAH PADA BEBERAPA SISTEM POLA TANAM
}

\author{
Muliatiningsih ${ }^{1 *}$, Zulaeha $^{2}$ \\ ${ }^{1}$ Teknik Pertanian, Universitas Muhammadiyah Mataram, muliatiningsih@ummat.ac.id \\ ${ }^{2}$ Balai Penyuluhan Pertanian, Dinas Pertanian Kota Mataram
}

\section{INFO ARTIKEL}

\section{RiwayatArtikel:}

Diterima: $15-02-2018$

Disetujui: 28-02-2018

Kata Kunci:

Erodibilitas Tanah

Pola Tanam

\section{ABSTRAK}

\begin{abstract}
Penelitian ini bertujuan untuk mengetahui kepekaan tanah atau tingkat erodibilitas tanah pada beberapa sistem pola tanam. Penelitian dilakukan di lapangan dengan pengambilan sampel tanah di desa Malaka kecamatan Pemenang Lombok Utara pada lahan dengan kemiringan $\geq 6^{\circ}$ dan analisis sifat fisika dan kimia tanah dilakukan di laboratorium Ilmu Tanah Fakultas Pertanian Universitas Mataram. Metode penelitian yang digunakan adalah metode deskriptif dengan pendekatan survei. Hasil penelitian menunjukkan bahwa sistem pola tanam yang berbeda yaitu lahan yang ditanami tanaman semusim (P1), lahan yang ditanami tanaman tahunan (P2) dan lahan yang ditanami secara tumpang sari (P3) pada lokasi penelitian menunjukkan nilai erodibilitas yang berbeda. Nilai erodibilitas tanah tertinggi terdapat pada P3 yaitu sebesar 0,70 sedangkan P2 dan P1 masing-masing sebesar 0,62 dan 0,69 . Nilai permeabilitas pada P2 yang relatif lebih rendah jika dibandingkan dengan P1 dan P3.
\end{abstract}

\section{A. LATAR BELAKANG}

Nusa Tenggara Barat (NTB) merupakan daerah yang memiliki lahan kritis yang cukup luas. Hal ini terlihat dari hasil inventarisasi lahan kritis di Balai Penelitian Daerah Aliran Sungai bahwa propinsi NTB dengan luas daerah 2.015.318, 84 ha terdapat lahan kritis seluas 853.289,66 ha (Status Lingkungan Hidup Indonesia, 2007). Selain itu NTB mempunyai topografi berbukit-bukit hingga bergunung, dimana luasannya mencapai 63,4\% (Suwardji, 2004). Daerah dengan topografi bergelombang hingga berbukit rentan terhadap erosi tanah, karena erosi dapat menyebabkan kerusakan tanah baik secara fisik, kimia, maupun biologi. Hal ini mempercepat terjadinya tanah miskin atau kritis, seperti penurunan produktivitas tanah, kehilangan bahan organik dan unsur hara di dalam tanah, dan juga kehilangan fungsi hidrologi tanah yang mengakibatkan tanah menjadi kurang produktif untuk dimanfaatkan sebagai lahan pertanian (Kurnia, Ahmad, dan Dariah, 2004).

Penggunaan lahan miring di desa Malaka kecamatan Pemenang belum mengacu pada usaha pelestarian sumber daya tanah dan air karena kondisi fisik lahan umumnya berlereng dan bersolum dangkal sehingga kemungkinan besar sangat mudah terjadi erosi. Terjadinya erosi tanah disebabkan karena semakin intensifnya sistem pertanian, pengolahan tanah, dan ketidaksesuaian antara penggunaan lahan dengan kemampuan lahan sehingga mempercepat terjadinya kerusakan tanah. Untuk memperbaiki atau mencegah terjadinya erosi yang perlu dipelajari diantaranya adalah erodibilitas tanah, seberapa besar kemampuan tanah untuk menahan energi kinetik hujan. Erodibilitas ini terkait dengan kondisi fisik dan kimia tanah, kebiasaan petani mengolah tanah, pola tanam, dan cara bercocok tanam (Sinukaban, 1989).

Setiap lahan memiliki tingkat kepekaan tanah yang berbeda-beda terhadap erosi, atau disebut erodibilitas tanah. Erodibilitas tanah dipengaruhi oleh tekstur tanah, kandungan bahan organik, struktur tanah dan permeabilitas tanah.

Sementara Wischmeier dan Mannering (1969) menyatakan bahwa erodibilitas alami (inherent) tanah merupakan sifat kompleks yang tergantung pada laju infiltrasi tanah dan kapasitas tanah untuk bertahan terhadap penghancuran agregat (detachment) serta pengangkutan oleh hujan dan aliran permukaan.

Suatu tanah yang mempunyai erodibilitas rendah mungkin mengalami erosi yang berat jika tanah tersebut terdapat pada lereng curam dan panjang, serta curah hujan dengan intensitas hujan yang selalu tinggi. Sebaliknya suatu tanah yang mempunyai erodibilitas tinggi, mungkin memperlihatkan gejala erosi ringan atau tidak sama sekali bila terdapat pada lereng yang landai, dengan penutupan vegetasi baik, dan curah hujan berintensitas rendah. Hudson (1978) juga menyatakan bahwa selain sifat fisik tanah, faktor pengelolaan atau perlakuan terhadap tanah sangat berpengaruh terhadap tingkat erodibilitas suatu tanah. Hal ini berhubungan dengan adanya pengaruh dari faktor pengelolaan tanah terhadap sifat-sifat tanah.

Berdasarkan uraian di atas, maka dilakukan sebuah kajian tentang erodibilitas tanah pada beberapa sistem pola tanam yang berbeda.

\section{B. METODE PENELITIAN}

\section{Lokasi Penelitian}

Penelitian ini mencakup penelitian di lapangan dan analisis di laboratorium. Pengambilan contoh tanah dilakukan di desa Malaka kecamatan Pemenang Lombok Utara. Lokasi penelitian memiliki kemiringan lahan $\geq 6^{\circ}$ dengan pola tanam yang berbeda. Analisis fisika dan kimia tanah dilakukan di laboratorium Ilmu Tanah Fakultas Pertanian Universitas Mataram. 


\section{Diskripsi Lokasi Penelitian}

Secara administratif lokasi penelitian terletak di desa Malaka kecamatan Pemenang, kabupaten Lombok Utara, Nusa Tenggara Barata. Topografi lahan sebagian berbukit dengan kemiringan lereng yang berkisar 1 $10 \%$. Lokasi penelitian yaitu lahan milik rakyat yang digunakan sebagai lahan budidaya dengan masingmasing pola tanam yang berbeda, yaitu lahan yang ditanami tanaman semusim (ketela pohon), lahan yang ditanami tanaman tahunan (jambu mete dan terdapat semak-semak dibawahnya tegakannya), dan lahan yang ditanami secara tumpang sari (talas + pisang).

Umur tanaman ketela pohon pada saat dilakukan penelitian yaitu $\pm 2,5$ bulan dengan jarak tanam $50 \mathrm{~cm}$ $\mathrm{x} 50 \mathrm{~cm}$, tanaman jambu mete $>20$ tahun dengan jarak tanam $5 \mathrm{~m} \times 5 \mathrm{~m}$, tanaman pisang \pm 3 bulan dengan jarak tanam $2 \mathrm{~m} \times 2 \mathrm{~m}$ serta tanaman talas \pm 2 bulan dengan jarak tanam $1 \mathrm{~m} \times 1 \mathrm{~m}$.

Data curah hujan tahunan di desa Malaka yaitu $202 \mathrm{~mm} /$ bulan.

\section{Metode Penelitian}

Metode yang digunakan dalam penelitian ini adalah metode deskriptif dengan pendekatan survei untuk pengambilan contoh tanah dan pengumpulan data pendukung dari lokasi penelitian. Data dan informasi yang dikumpulkan, dianalisis dan diinterpretasikan serta dibahas untuk digunakan sebagai bahan acuan dalam menarik kesimpulan dan pemberian saran serta rekomendasi.

\section{Studi Pendahuluan}

Studi pendahuluan meliputi survei lokasi dan wawancara dengan masyarakat setempat yang dilakukan untuk memperoleh data dan informasi awal dalam menentukan lokasi penelitian.

\section{Survei Lapang dan Pengambilan Contoh Tanah}

Survei lapang dilakukan untuk menentukan lokasi pengambilan data dan contoh tanah pewakil. Contoh tanah diambil pada tiga sistem pola tanam yang berbeda, yaitu :

P1 : lahan yang ditanami tanaman semusim (ketela pohon)

P2 : lahan yang ditanami tanaman tahunan (jambu mete dan terdapat semak belukar)

P3 : lahan yang ditanamin secara tumpang sari (pisang dan ketela)

Contoh tanah yang diambil meliputi contaoh tanah terusik untuk keperluan analisis sifat kimia tanah (bahan organik) dan sifat fisik tanah ( tekstur dan struktur tanah) serta contoh tanah tak terusik untuk keperluan analisis sifat fisik tanah (permeabilitas). Pengambilan contoh tanah terusik dilakukan dengan menggunakan ring sample. Contoh tanah diambil pada kedalaman 0-20 cm dari permukaan tanah. Pengambilan contoh tanah menggunakan teknik line transect plot (Mueller-Dumbois dan Ellenberg, 1974).

Persiapan dan Analisis Contoh Tanah di Laboratorium

Contoh tanah komposit dikering anginkan, ditumbuk dan diayak dengan mata ayak 0,5 mm - 2,0 mm untuk keperluan analisis kimia. Tanah tak terusik dipergunakan secara langsung untuk keperluan analisis permeabilitas tanah.

\section{Analisis Data}

Data yang diperoleh diinterpretasikan dalam bentuk tabel dan atau gambar. Informasi yang diperoleh dari tabel dan atau gambar tersebut dideskripsikan untuk mengetahui indeks dan tingkat erodibilitas tanah.

\section{Parameter Pengamatan}

Parameter yang diamati tercantum pada Tabel 1. sebagai berikut :

Tabel 1.

Parameter penelitian dan Metode Pengukurannya

\begin{tabular}{|l|l|l|}
\hline No & Parameter & Metode Pengukuran \\
\hline 1. & Tekstur Tanah & Metode Pipet \\
\hline 2. & $\begin{array}{l}\text { Permeabilitas } \\
\text { Tanah }\end{array}$ & Permeameter \\
\hline 3. & Struktur Tanah & Metode Lilin \\
\hline 4. & $\begin{array}{l}\text { Bahan organik } \\
\text { tanah }\end{array}$ & Walkley and Black \\
\hline 5. & Erodibilitas & $\begin{array}{c}100 \mathrm{~K}=2,1 \mathrm{M}^{1,14} \times 10^{-4} \mathrm{x}(12-\mathrm{a})+ \\
3,25(\mathrm{~b}-2)+2,5(\mathrm{c}-3)\end{array}$ \\
\hline
\end{tabular}

\section{HASIL DAN PEMBAHASAN}

\section{Deskripsi Lokasi Penelitian}

Desa Malaka memiliki wilayah seluas $12,41 \mathrm{~km}^{2}$ dengan rata-rata curah hujan yang diterima sebesar $202 \mathrm{~mm} /$ bulan. Pada lokasi penelitian tidak terdapat sistem irigasi sehingga sistem pertanian di lokasi tersebut sangat bergantung pada air hujan atau sering disebut dengan sistem pertanian tadah hujan (BPS, 2010). Di lain pihak, desa ini bertopogafi berombak dan sebagian besar masyarakatnya memanfaatkan wilayah tersebut untuk bercocok tanam. Komoditi yang umumnya dibudidayakan di daerah tersebut antara lain ubi jalar, jagung, ketela pohon, kacang tanah dan tanaman perkebunan seperti kelapa, kopi serta jambu mete.

Tabel 2.Gambaran Umum Lokasi Penelitian

\begin{tabular}{|c|c|c|c|c|c|c|}
\hline Sistem & Umur & Jarak & Tinggi & Kemiringan & Tekstur & Struktur \\
\hline Tanam & Tanaman & Tanam & Tanaman & Lereng & Tanah & Tanah \\
\hline P1 & 2,5 bulan & $\begin{array}{l}50 \times 50 \\
\mathrm{~cm}\end{array}$ & $50 \mathrm{~cm}$ & $6,5^{\circ}$ & Pasir & Granuler \\
\hline P2 & $\begin{array}{l}>20 \\
\text { tahun }\end{array}$ & $5 \times 5 \mathrm{~m}$ & $\geq 3 \mathrm{~m}$ & $6,5^{\circ}$ & Pasir & Granuler \\
\hline P3 & $\begin{array}{l}2 \text { bulan } \\
3 \text { bulan }\end{array}$ & $\begin{array}{l}1 \times 1 \mathrm{~m} \\
2 \times 2 \mathrm{~m}\end{array}$ & $\begin{array}{l}50 \mathrm{~cm} \\
1,5 \mathrm{~m}\end{array}$ & $6,0^{\circ}$ & Pasir & Granuler \\
\hline
\end{tabular}

Keterangan : P1 : lahan yang ditanami tanaman semusim (ketela pohon); P2 : lahan yang ditanami tanaman tahunan (jambu mete); P3 : lahan yang ditanami secara tumpang sari (talas + pisang) 
Dari tabel 2. Dapat diketahui bahwa lokasi penelitian terletak pada daerah berombak dengan kemiringan lereng $\geq 6,0^{\circ}$. Pada kondisi demikian, masyarakat melakukan usaha tani yang belum sesuai dengan prinsip-prinsip konservasi lahan terutama manajemen tanaman. Penanaman tanaman belum mengikuti garis kontur bukit, belum dilakukan pembuatan teras untuk memperkecil laju limpasan dan tanpa tanaman penutup tanah (cover crop). Hal tersebut menyebabkan lahan rentan terhadap erosi, mengingat tekstur tanahnya termasuk dalam kelas tekstur pasir dan struktur tanahnya granuler.

\section{Erodibilitas Tanah}

Sistem pola tanam yang berbeda yaitu lahan yang ditanami tanaman semusim (P1), lahan yang ditanami tanaman tahunan (P2) dan lahan yang ditanami secara tumpang sari (P3) pada lokasi penelitian menunjukkan nilai erodibilitas yang berbeda (Gambar 1.) tetapi memiliki harkat yang sama, yaitu termasuk dalam kategori sangat tinggi (Arsyad, 2000).

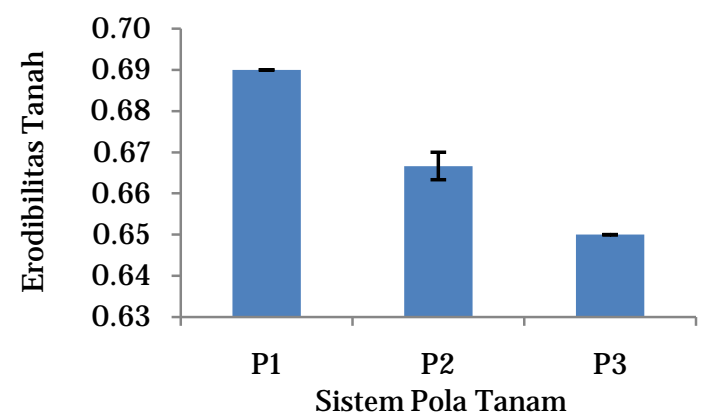

Gambar 1. Nilai Erodibilitas Tanah Pada Sistem Pola Tanam yang Berbeda

Keterangan: P1 : lahan yang ditanami tanaman semusim (ketela pohon); P2 : lahan yang ditanami tanaman tahunan (jambu mete dan terdapat semak-semak); P3 : lahan yang ditanami secara tumpang sari (pisang dan talas)

Pada gambar 1. Terlihat bahwa nilai erodibilitas tanah tertinggi terdapat pada $\mathrm{P} 3$ yaitu sebesar 0,70 sedangkan P2 dan P1 masing-masing sebesar 0,62 dan 0,69. Tingginya nilai erodibilitas tanah pada P3 menunjukkan bahwa tingkat ketahanan tanah terhadap energi kinetik butiran air hujan rendah. Hal ini dikarenakan umur tanaman pisang ( \pm 3 bulan) dan talas ( $( \pm 2$ bulan) yang masih muda dengan jumlah daun yang relatif sedikit sehingga memiliki tajuk yang tidak terlalu lebar, yang pada akhirnya kurang mampu melindungi permukaan tanah dari butiran air hujan.

Efektifitas tanaman penutup dalam mengurangi erosi tergantung pada ketinggian dan kontinuitas penutupan, kerapatan penutup tanah dan kerapatan perakaran. Vegetasi mampu menangkap (intersepsi) butir air hujan sehingga energi kinetiknya terserap oleh tanaman dan tidak menghantam langsung pada tanah. Besarnya intersepsi sangat tergantung pada jenis tanaman dan kerapatan tanaman.
Selain itu, kemantapan struktur tanah pada P3 rendah mengingat tekstur tanah P3 didominasi oleh fraksi pasir (90\%) yang menyebabkan P3 sangat peka terhadap erosi. Suripin (2004) menyatakan bahwa tanah-tanah yang paling tahan terhadap erosi adalah tanah-tanah lempung. Karena tanah lempung memiliki kemantapan struktur dan kapasitas penampungan air yang lebih tinggi.

P2 memiliki nilai erodibilitas terendah yang menggambarkan daya tahan lahan terhadap perusakan oleh butir air hujan lebih tinggi dari P1 dan P3. Luasan tajuk pada tanaman jambu mete yang lebih lebar mengakibatkan kemungkinan air hujan yang terintersepsi pada daun lebih lebih besar, sehingga air yang mencapai permukaan tanah relatif berkurang yang pada akhirnya menurunkan daya perusak air hujan terhadap tanah. Selain itu, terdapatnya tanaman semak belukar diantara tanaman jambu mete mengakibatkan tanah lebih terlindungi dari energi perusak butir-butir hujan. Energi tersebut merupakan faktor utama penyebab erosi pada tanah-tanah yang tidak terlindungi. Rahardjo, Kusnarta dan Padusung (2005) juga menyatakan bahwa efektivitas tanaman untuk mengurangi laju kehilangan tanah terkait erat dengan kemampuan tanaman dalam hal : intersepsi dan sekaligus memperpendek jarak jatuh butir hujan, penutupan dan memperkasar permukaan tanah, serta meningkatkan ketahanan tanah terhadap erosi. Keempat kemampuan tanaman tersebut ditunjukkan oleh tinggi dan kontinyuitas mahkota daun, kepadatan dan sistem perakaran tanaman, serta bahan organik yang ditinggalkan.

Bahan organik yang masih berbentuk seresah, seperti ranting dan daun yang belum hancur yang menutupi permukaan tanah merupakan pelindung tanah terhadap kekuatan perusak butir-butir hujan yang jatuh. Hal ini ditunjukkan pada Gambar 2. dimana kandungan bahan organik pada P2 sebesar 1,59\% lebih tinggi dari kandungan bahan organik pada P1 sebesar 0,97\% dan P3 sebesar 1,07\%.

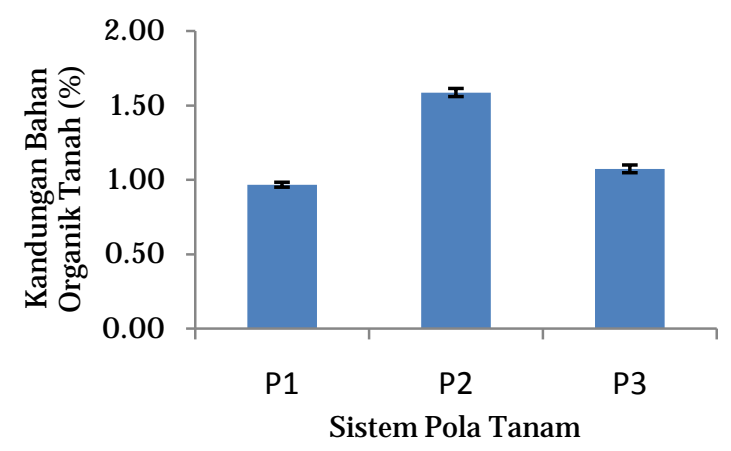

Gambar 2. Kandungan Bahan Organik Tanah Pada Sistem Pola Tanam yang Berbeda

Keterangan: P1 : Lahan yang ditanami tanaman semusim (ketela pohon); P2 : Lahan yang ditanami tanaman tahunan (jambu mete dan terdapat semak-semak); P3 : Lahan yang ditanami secara tumpang sari (pisang dan talas)

Tajuk tanaman yang lebih lebar dan banyaknya seresah pada P2 memungkinkan tanah lebih terlindungi dari daya perusak air hujan dan menghambat aliran 
permukaan, sehingga kecepatan alirannya lebih lambat dan relatif tidak merusak. Hal ini sejalan dengan Suripin (2004) yang mengemukakan bahwa sisa-sisa tanaman yang tersebar di atas permukaan tanah mempunyai efektivitas yang tinggi dalam melindungi tanah dari energi kinetik butiran air hujan daripada tajuk tanaman dengan persentase penutupan tanah yang sama. Karena sisa-sisa tanaman tersebut menempel langsung pada permukaan tanah sehingga energi dari butir-butir hujan yang menimpa tanah praktis sama dengan nol.

Seresah yang membusuk kemudian dapat menjadi bahan organik dan meningkatkan kandungan bahan organik tanah pada P2. Bahan organik yang sudah mengalami pelapukan mempunyai kemampuan menyerap dan menahan air yang tinggi, sampai duatiga kali berat keringnya. Akan tetapi, kemampuan menyerap air ini hanya merupakan faktor kecil dalam mempengaruhi kecepatan aliran permukaan. Pengaruh utama bahan organik adalah memperlambat aliran permukaan, meningkatkan infiltrasi, dan memantapkan agregat tanah (Arsyad, 2000).

Hal ini juga didukung oleh nilai permeabilitas pada P2 yang relatif lebih rendah (Gambar 3.) jika dibandingkan dengan P1 dan P3. Keberadaan sumbersumber bahan organik tanah secara in situ mampu meningkatkan daya menahan air tanah dan mengurangi jumlah air yang dapat diloloskan (Rahardjo, dkk. 2005).

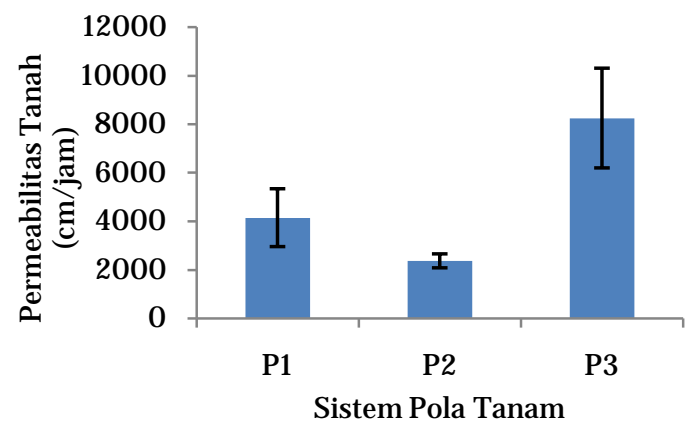

Gambar 1. Nilai Permeabilitas Tanah Pada Sistem Pola Tanam yang Berbeda

Keterangan : P1 : Lahan yang ditanami tanaman semusim (ketela pohon); P2 : Lahan yang ditanami tanaman tahunan (jambu mete dan terdapat semak-semak); P3 : Lahan yang ditanami secara tumpang sari (pisang dan talas)

Di sisi lain, persentase fraksi lempung yang lebih tinggi pada P2 daripada P1 dan P3 (lampiran 1.d) juga berperan positif terhadap peningkatan daya simpan air tanah. Fraksi lempung memiliki luas permukaan yang lebih besar setiap satuan beratnya sehingga lebih aktif di dalam reaksi-reaksi fisikokimia yang terjadi di dalam tanah. Perakaran jambu mete juga dapat meningkatkan agregasi tanah karena akarnya menembus ke lapisan tanah yang dalam, dan jika membusuk akarnya dapat menjadi sumber bahan organik bagi lapisan-lapisan tanah baik lapisan atas maupun lapisan bawah (Hardjowigeno, 2009).

\section{SIMPULAN DAN SARAN}

Dari hasil penelitian dan pembahasan dapat diperoleh kesimpulan sebagai berikut :
1. Sistem pola tanam yang berbeda mempengaruhi nilai erodibilitas tanah.

2. Nilai erodibilitas tanah tertinggi $(0,70)$ terdapat pada sistem pola tanam P3 (tumpang sari) dan terendah pada sistem pola tanam P2 (tanaman tahunan) yakni 0,62.

3. Kandungan bahan organik pada P2 sebesar 1,59\% lebih tinggi dari kandungan bahan organik pada P1 sebesarn 0,97\% dan $\mathrm{P} 3$ sebesar 1,07\%.

4. Nilai permeabilitas pada P2 yang relatif lebih rendah jika dibandingkan dengan P1 dan P3.

\section{UCAPAN TERIMA KASIH}

Penulis mengucapkan terima kasih kepada Universitas Muhammadiyah Mataram yang telah membiayai penelitian ini melalui Dana Hibah Penelitian Universitas.

\section{DAFTAR RUJ UKAN}

[1] Arsyad, S, Konservasi Tanah dan Air, Lembaga Sumberdaya Informasi-Institut Pertanian Bogor, IPB Press, Bogor,2000.

[2] Hardjowigeno, S, Ilmu Tanah, Akademika Pressindo, J akarta, 2009.

[3] Hudson, N, Soil Conservation, Bastford, London, 1978.

[4] Kurnia, U., Ahmad R., dan Ai Dariah. 2004. Teknologi Konservasi Tanah Pada Lahan Kering Berlereng. Pusat Penelitian Tanah dan Agroklimat Bogor. J awa Barat.

[5] Mueller-Dombois, D. And H. Ellenberg. 1974. Aims and Methods Vegetation Ecology. John Wiley and Sons. London.

[6] Rahardjo, Kusnarta dan Padusung. 2005.Konservasi Tanah dan Air. Mataram University Press. Mataram.

[7] Sinukaban, 1989. Konservasi Tanah dan Air di Daerah Transmigrasi. PT. Indeco Duta Utama International Development Consultants Berasosiasi dengan BCEOM.

[8] Status Lingkungan Hidup Indonesia. 2007. Lahan dan Hutan. Kementerian Negara Lingkungan Hidup, Jakarta.

[9] Suripin. 2004. Pelestarian Sumberdaya Tanah dan Air. ANDI. Yogyakarta.

[10] Suwardji. 2004. Mencari Skenario Pengembangan Pertanian Lahan Kering yang Berkelanjutan Di Propinsi NTB. Makalah utama yang disampaikan dalam seminar nasional "Pemberdayaan Petani Miskin Di Lahan Marjinal Melalui Inovasi Teknologi Tepat Guna Di Mataram".

[11] Wischmeier, W. H., dan J. V. Mannering. 1969. Relation of Soil Properties to its Erodibility. Soil Sci. Am.

[12] Wischmeier, W. H., dan Smith. 1978. Predicting Rainfall Erosion Losses a Guide to Conservation Planning. US Dep. of Agri. Handbook No. 537. 